\title{
OBSÁHLÁ CESTA KRAJEM CESTOVNÍHO RUCHU ČESKOSLOVENSKA
}

\author{
Tomáš Kavka
}

Jan ŠTEMBERK - Ivan JAKuBeC, Cestovní ruch pod dohledem třetí řiše, Karolinum, Praha 2018, 310 s., ISBN 978-20-246-4127-0.

Pavel MǗcKe - Lenka KRÁTKÁ (ed.) Turistická odysea. Krajinou soudobých dějin cestování a cestovního ruchu v Československu v letech 1945 až 1989, Orální historie a soudobé dějiny, Karolinum, Praha 2018, 670 s., ISBN 978-80-246-4055-6.

Historie cestovního ruchu, výletů za hranice všedních dní a obecně mobilita za účelem odpočinku a trávení volného času patři již dlouhou dobu k respektovaným oborům kulturních, hospodářských nebo sociálních dějin. Jde o téma, které souvisí s množstvím dalších, a je tedy velmi dobrou zprávou, že se i v českém prostředí vyvinulo v posledním desetiletí v širší obor zájmu, podpořený několika granty a zaštítěný respektovanými odborníky. ${ }^{1} \mathrm{~V}$ tomto směru hraje velkou roli kromě obecného rozšiřování dějin každodennosti a volného času i rozvoj turistického průmyslu a možnosti specializovaného studia této disciplíny třeba i na vysoké škole. ${ }^{2}$

V rámci historie cestovního ruchu se v českém prostředí jako odborník etabloval Jan Štemberk. Ten je také spoluautorem první recenzované knihy věnované protektorátu a do druhé pojednávající o letech následného období budování komunismu přispěl studií. V jeho prrípadě jde o pokračování dlouhodobého výzkumu, který započal před více než deseti lety v tématu období první republiky. ${ }^{3}$ Štemberk téma chápe hlavně prizmatem hospodářských dějin. V nich se stal specialistou ještě na Karlově univerzitě a se svým domovským pracovištěm, Ústavem hospodářských a sociálních dějin FF UK, neustále udržuje kontakt. Toho je důkazem i spoluautorství recenzované publikace Ivanem Jakubcem, který patří ke klíčovým osobám výše zmíněného pracoviště a obecně hospodářských dějin 20 . století.

Bádání v kulturně-sociálních souvislostech, postavené zčásti na využití vzpomínek pamětníků, je zase primární metodou na pracovišti Orální historie Akademie věd ČR, které stojí za druhou recenzovanou publikací. Zde se po realizaci prací věnovaných politickým a mocenským aktérům období pozdní normalizace ${ }^{4}$ postupně přechází $\mathrm{k}$ bádání o různých podobách každodennosti společnosti, v níž hrály možnosti využití volného času důležitou roli. ${ }^{5} \mathrm{Za}$ výzkumem turismu a cestování v období diktatury KSČ stojí zdejší tým vedený Pavlem Mückem a Lenkou Krátkou. Ti dali ve spolupráci $\mathrm{s}$ dalšími kolegy z pracoviště, jejich studenty i externisty (viz příspěvek J. Štemberka) dohromady obsáhlou kolektivní monografii s př́spěvky 11 autorů, která mapuje z mnoha pohledů různá témata, tradice, podmínky i vývoj cestovního ruchu v Československu let 1945-1989.

V obou knihách je snaha téma po svém uchopit vysvětlována. Jejich autorské kolektivy si jsou rovněž dobře vědomy, že jej nelze popsat až do úplného vyčerpání. Štemberk s Jakubcem si cestovní ruch definují jako ,,dočasnou změnu místa pobytu, která v domácím ruchu nepřekračuje šest měsiců a v mezinárodním jeden rok, která je dobrovolná a nesleduje výdělečné účely“ (s. 7). Logicky jim stranou zůstává nacistická mašinérie transportů rasově segregovaného obyvatelstva a politických odpůrců režimu, nucených nasazení pracujících protektorátu i zkušenosti agentů a frontových vojáků. Pohybují se tak v rámci poznání fungování protektorátu a jejich práce je pak založena na pečlivém a obsáhlém archivním bádání (více než 40 archivů bylo k získání širokého pohledu navštíveno), které je doplněno úryvky z dobového tisku. Ačkoli využívají k objasnění souvislostí zahraniční literatury hlavně německojazyčné provenience, nepouští se do př́lišného teoretizování. Naopak téma představují v jas-

\footnotetext{
${ }^{1}$ První větší projekt byl podpořen GA ČR 409/07/P463 v letech 2007-2009 s názvem „Limity a možnosti cestovního ruchu v meziválečném Československu“. I obě recenzované knihy vznikly v rámci realizace projektů GAČR (GAČ́R č.16-07164S „Pod dohledem třetí ŕíše. Cestovní ruch 1939 až 1945“; resp. GAČR č. 15-08130S „Malé“ a „velké“ dějiny českého/československého cestování a cestovního ruchu 1945-1989). V poslední době byl v českém prostředí zkoumán turismus i z pohledu antropologie viz Barbora Půtová, Antropologie turismu, Karolinum, Praha, 2019.

2 Viz Vysoká škola ekonomická, Katedra cestovního ruchu - https://kcr.vse.cz/ (shlédnuto 15. 6. 2020).

3 Jan Štemberk, Fenomén cestovního ruchu. Možnosti a limity cestovního ruchu v meziválečném Československu, Nová tiskárna, Pelhřimov 2009.

${ }^{4}$ Viz Miroslav VANĚK - Pavel UrbášEK, Vitězové? Poražení?: životopisná interwiew, I. díl. Disent v obdobi tzv. normalizace; II. díl. Politické elity v obdobi tzv. normalizace, Praha 2005; Miroslav VANĚK, Ostrůvky svobody. Kulturní a občanské aktivity mladé generace v 80. letech v Československu, Praha 2002.

${ }^{5}$ V poslední době např́íklad Miroslav VANĚK - Pavel MÜCKE, Přiběhy neobyčejných profesí, Praha 2014 nebo Petra SchInDLER-WISTEN, O chalupách a lidech, Praha 2017.
} 
ně strukturovaných bodech - politika cestovního ruchu, její předpoklady a následné podmínky, ubytování a stravování, doprava, tuzemský, resp. zahraniční cestovní ruch. V tomto směru najdeme v každé z kapitol kvantifikovaný výčet dějů, zákonů a statistik, občas okomentovaný zprávami z dobového tisku. Vzniká nám tak třeba v předpokladech turismu jasná definice, kdo teoreticky mohl a nemohl cestovat (rozsáhlý a právně podložený je i vývoj omezení židů), kolik lidí cestování využilo, jakož i popis prostorových možností (s výčtem a důvody omezení oblastí) i tehdejší předpisy ochrany př́rody. Nejednou se jasně projevuje, že Štemberk má vedle historie také právnické vzdělání. Čtenár̆ tak ocení, že dostane téměř vyčerpávající popis různých podmínek i statistik cestování. Co je knize trochu na škodu (ač u knih blízkých hospodářským dějinám běžné), vytrácí se z něj samotný cestovatel a jeho přijímání turismu v krizové historické situaci. Ač v rámci zkoumané doby je přeci jenom těžké narazit na vzpomínky či využití ego-dokumentů, kniha v tomto smyslu působí trochu jako lidmi „nezabydlená“. V aktuálním popkulturním kontextu, kdy má česká společnost zkušenost s televizní docureality Dovolená v protektorátu ${ }^{6}$, by zpracování konkrétního lidského osudu bylo jistě přínosné. Ovšem jako obsažná př́íručka a rozcestník k jednotlivým tématům je kniha více než užitečná.

V tomto směru, alespoň ve většině příspěvků, Mücke s Krátkou a jejich týmem nabízí širší, nejen klasickými psanými archiváliemi definovanou publikaci. Metodologicky inspirativních přístupů v ní najdeme větší množství, zejména vyčnívá orálně historický výzkum, logicky vyplývající z povahy zaměření pracoviště autorů. Nicméně, můžeme-li se v první recenzované knize o protektorátu spolehnout na jasnou strukturu a s ní spojenou dynamiku kapitol, v publikaci o turismu v komunistické diktatuře často narážíme na útržkovitost a do děje se tak s každým novým autorem musíme znovu a znovu dostávat. V úvodu mluví o obsahu a posunech textu autoři jako odpovídající deduktivní logice od velkých dějin $\mathrm{k}$ jednotlivým sondám. Přitom třeba hned první kapitola psaná zahraničním specialistou Sune Bechman Pedersenem se více než na souvislosti turismu mezi západními zeměmi a východním blokem koncentruje na kontext Skandinávie. Je dobré tak ocenit, že se editorům práci švédského historika českému čtenáři podařilo představit, ovšem jde přeci jenom spíše o studii specializovanou než generalizující. Dílo v tomto prrípadě trpí problémem typickým pro tzv. kolektivní monografie, že se i přes snahu autorů v úvodu i krátkém závěrečném resumé nedaří obsah knihy uchopit jako celek. A možná by do budoucna stálo za to se na základě všech shromážděných pramenů pokusit o klasické chronologické zpracování, jaké předestřel právě Štemberk s Jakubcem v druhé recenzované knize o cestovním ruchu let 1938-1945. Autoři by byli schopni nejspíše na základě vybraných studií a jejich metodologického uchopení spolu s užitím jimi oblíbených statistik a právních výkladů, sestavit dějově plynulý, tematicky strukturovaný a dynamicky se vyvíjející text. Souvislý př́běh a jasné odpovědi v kontextu jednoho tématu pro celé období let 1945-89 tedy v recenzované kolektivní monografii nehledejme.

Tento spíše strukturální nešvar ovšem nikterak nesnižuje záslužnou a řemeslně kvalitně provedenou práci, která dává nový potenciál i k veřejné prezentaci dějin i historické logiky současné podoby cestovního ruchu a turismu. Obvykle jsou tyto části dějin využivány jako dokreslení komerčních turistických veletrhů či např́klad v kontextu představení návštěvnických míst $\mathrm{v}$ informačních centrech a městských expozicích, popřípadě u prezentací volnočasových žánrů. Z poslední doby lze $\mathrm{v}$ českém prostředí takto poukázat na výstavu o historii Svazu českých turistů v Národním mu$z^{7} u^{7}$ či prezentaci horolezectví, které dostalo svoji novou expozici ve společném projektu turnovského muzea Českého ráje a německého Bad Schandau. Ta ukazuje zmíněné sportovní odvětví jako genius loci Českého ráje, resp. Labských pískovců lákající množství turistů. ${ }^{8}$ Bohatý a tematicky pestrý obsah obou knih by mohl být podkladem $\mathrm{k}$ materiálům výstavy či stálé expozice o cestovním ruchu, v němž by se ukázal mnohovrstevnatý příběh proměn mobility obyvatelstva souvisejících s ekonomickým, mocenským, technologickým i ekologickým stavem společnosti, který značně formuje myšlení a intelektuální horizont stovek tisíc lidí.

\footnotetext{
${ }^{6}$ Dovolená v Protektorátu, námět a scénář Zora Cejnková, Česká televize 2015 - stránky pořadu: https://www.ceskatelevize.cz/porady/ 10871520054-dovolena-v-protektoratu/ (shlédnuto 30. 3. 2020).

7 Výstava s názvem Zdrávi došli! byla připravena ke 130. výročí založení Klubu českých turistů, viz https://www.nm.cz/o-nas/novinky/zdravi-dosli-narodni-muzeum-otevira-novou-vystavu-v-narodnim-pamatniku-na-vitkove (shlédnuto 15. 6. 2020).

8 Viz https://www.muzeum-turnov.cz/horolezecka-expozice/ (shlédnuto 14. 6. 2020).
} 